NBER WORKING PAPER SERIES

\title{
INFORMATION, DECISIONS, AND PRODUCTIVITY: ON-BOARD COMPUTERS AND CAPACITY UTILIZATION IN TRUCKING
}

\author{
Thomas N. Hubbard \\ Working Paper 8525 \\ http://www.nber.org/papers/w8525 \\ NATIONAL BUREAU OF ECONOMIC RESEARCH \\ 1050 Massachusetts Avenue \\ Cambridge, MA 02138 \\ October 2001
}

I would like to thank Ann Merchant for excellent research assistance and many individuals at trucking firms for useful discussions. I also thank Dietmar Harhoff, Scott Stern, Jack Triplett, and seminar participants at Brookings, NBER, Stanford, and the ZEW for comments. I gratefully acknowledge support from NSF grant SES-9975413. The views expressed herein are those of the author and not necessarily those of the National Bureau of Economic Research.

(C) 2001 by Thomas N. Hubbard. All rights reserved. Short sections of text, not to exceed two paragraphs, may be quoted without explicit permission provided that full credit, including (C) notice, is given to the source. 
Information, Decisions, and Productivity:

On-Board Computers and Capacity Utilization in Trucking

Thomas N. Hubbard

NBER Working Paper No. 8525

October 2001

JEL No. E23, D24, L92, O33

\begin{abstract}
Productivity reflects not only how efficiently inputs are transformed into outputs, but also how well information is brought to bear on resource allocation decisions. This paper examines this empirically by looking at how on-board computer (OBC) adoption has affected capacity utilization in the trucking industry. Estimates using 1997 data indicate that capacity utilization has increased by an average of 13\% among trucks for which advanced OBCs have been adopted. The average benefits to adopters are higher in 1997 than 1992, suggesting lags to the returns to adoption, and are highly skewed across hauls. The 1997 estimates imply that OBC-enabled improvements in communications and resource allocation decisions have led to a $3 \%$ increase in capacity utilization in the industry, which translates to billions of dollars of annual benefits. The commercialization of other wireless networking applications has the potential to generate analogous benefits in other contexts.
\end{abstract}

Thomas N. Hubbard

University of Chicago - GSB

1101 E. $58^{\text {th }}$ Street

Chicago, IL 60637

and NBER

thomas.hubbard@gsb.uchicago.edu 


\section{Introduction}

Theoretical links between economic performance and the use of information, such as those in Hayek's (1945) famous analysis of economic organization, are at the core of a recurring theme in the productivity literature: the premise that information technology (IT) offers opportunities for large productivity gains. Empirical evidence showing links between IT diffusion and productivity has been scarce until recently, however. ${ }^{1}$ Researchers in the field refer to this as "the productivity paradox." The difficulty of finding relationships between IT use and productivity using aggregate data is well-summarized by Solow's oft-cited observation: "You can see the computer age everywhere except in the productivity statistics."

This paper examines micro-level empirical relationships between IT use and productivity in the trucking industry in the 1990s. Productivity in this industry, as elsewhere in the economy, depends critically on how well information is brought to bear on resource allocation decisions. ${ }^{2}$ Supply and demand conditions change constantly; forecasting exactly when and where trucks will be available and exactly when and where shippers will demand service is difficult more than a few hours in advance. Information about trucks' availability and value in different uses is highly dispersed, and communication costs create situations where the individuals deciding how individual trucks should be used - usually, dispatchers - do not have good information about trucks' availability. Trucks are not always allocated to their most valuable use as a consequence. Poor matches between capacity and demands lead to underutilization in the form of idle trucks and partially-full or empty trailers.

In particular, I examine how on-board computer (OBC) use has affected capacity utilization. OBCs help managers at trucking firms or divisions monitor trucks and drivers. Low-end devices trip recorders - make truck drivers' activities more contractible and help mechanics diagnose engine

${ }^{1}$ Athey and Stern (2000), Brynjolffson and Hitt (1996), Lehr and Lichtenberg (1998), Lichtenberg (1995), Oliner and Sichel (2000). See Brynjolffson and Hitt (2000) and Brynjolffson and Yang (1996) for surveys of the evidence.

${ }^{2}$ That firms pay thousands of dollars for supply chain management software that provides managers up-to-date information about the status of production processes and inventories testifies that information about capacity is valuable and costly to obtain in other contexts. 
problems. High-end devices - electronic vehicle management systems (EVMS) - also provide dispatchers real-time information about trucks' location and an efficient means of communicating with distant drivers. These additional capabilities let dispatchers make and implement better resource allocation decisions: they can allocate trucks across existing orders and market excess capacity better than they otherwise could. This, in turn, can lead to better matches between truck capacity and demands within and across firms. Better matches boost capacity utilization and productivity in the industry.

I find that $\mathrm{OBC}$ use has increased capacity utilization significantly in the industry. Estimates using 1997 data indicate average increases in capacity utilization of 13\% among adopters of advanced OBCs. These increases appear to be almost entirely due to EVMS' advanced features, which lower communication costs and improve resource allocation decisions. There is little evidence of truck utilization increases due to incentive improvements. The average benefits to adopters are higher in 1997 than 1992, suggesting lags to the returns to adoption, and are highly skewed across hauls. About three-quarters of the capacity utilization benefits are on trucks that haul goods long distances in non-specialized trailers. The 1997 estimates imply that OBC-enabled improvements in decision-making have led to $3 \%$ higher capacity utilization in the industry, which translates to about $\$ 16$ billion in annual benefits. These benefits are likely to increase as complementary economic institutions such as centralized markets develop in the industry and as diffusion becomes more widespread.

This study stands at the intersection of the productivity, economics of technology, and economics of organizations literatures, and is important for several reasons. First, it provides strong evidence of productivity gains from IT adoption. There is no "productivity paradox" in trucking. This study adds to a growing set of studies that document relationships between productivity and IT use, some of which are cited above. Second, as the Hayek cite indicates, understanding relationships between informational and resource allocation improvements is central for understanding the performance of economic organizations and how decreases in information costs lead to increases in welfare. This is one of the first empirical studies to examine these relationships in detail. An advantage of this paper's micro-level industry study approach (shared by Athey and Stern (2000)) is that one can understand exactly how and why IT use leads to productivity gains. Third, truck- 
tracking is one of the first commercially-important wireless networking applications. Wireless networking applications are expected to diffuse more broadly in the economy in the near future; this study helps researchers understand their economic implications. The conclusion that OBCs have generated large benefits in trucking suggests that new networking applications have the potential to generate large welfare gains elsewhere. ${ }^{3}$ Last, few individual applications have the potential for as significant a macroeconomic effect as $\mathrm{OBC}$-enabled truck-tracking. OBCs fundamentally changed how resource allocation decisions were made in an industry that interacts with most sectors of the economy and amounts to about $6 \%$ of GDP (including the value-added produced by private fleets). OBC diffusion and related logistical improvements were non-trivial contributors to economic growth in the U.S. during the 1990s.

An outline of the rest of the paper follows. The next section describes the institutional setting and depicts how OBCs improve resource allocation decisions in trucking. Section 3 presents the data and the basic empirical patterns. Section 4 outlines the empirical framework. Section 5 discusses the estimation results. Section 6 concludes.

\section{Information and Capacity Utilization in Trucking}

The physical part of the production process in trucking is simple. Cargo is loaded onto a truck, or a truck's trailer. An individual - a driver - drives the truck to its destination, where the cargo is unloaded. The output of the production process is the movement of cargo.

All else equal, costs per unit of output fall with capacity utilization. The per-unit cost of moving cargo on a truck increases less than proportionately with the weight of the cargo, and firms bear opportunity costs when trucks are idle, especially when idle trucks imply idle drivers. Truck capacity is lumpy and location- and time-specific. Capacity utilization is high when trucks haul a series of full loads, each of which starts close to and soon after the previous one finished.

Achieving high levels of capacity utilization is easy in some circumstances, but hard in others. When shippers have consistent demands to transport full loads of cargo back and forth between two points, high utilization rates can be achieved by dedicating trucks and drivers to a

\footnotetext{
${ }^{3}$ See Gordon (2000) for a skeptic's view.
} 
shipper and route. Most situations are not like this, however. Individual shippers usually do not have demands for both legs of a round trip and shipments often do not fill trailers. In such situations, high capacity utilization requires trucks to haul different shippers' cargo on the same run.

Capacity utilization thus depends largely on how well individuals can identify and agglomerate complementary demands onto individual trucks. Higher quality matches increase capacity utilization by keeping trucks on the road and loaded more, and therefore raise truck drivers' productivity. ${ }^{4}$

It follows that understanding the link between information and capacity utilization requires some understanding of the institutions that facilitate matching, individuals' role within these institutions, and how informational improvements lead to better matches both directly and through organizational changes. This is the topic of the next subsection.

\section{Institutions and Market Clearing}

Market clearing in trucking is unlike that in textbook economics models. It does not take place in centralized markets in which participants simply observe prices and decide how much capacity to sell to or buy from the market. Centralized markets have traditionally been unimportant in trucking, in large part because capacity and demands are highly differentiated in terms of time, location, and equipment characteristics. Organizing centralized markets that are so narrowly-defined is costly relative to the benefits such markets would generate. ${ }^{5}$ Instead, capacity and demand are matched in a highly decentralized manner in which buyers, sellers, and intermediaries engage in costly search. These parties identify trading opportunities by contacting each other directly rather than through markets.

One way complementary demands are identified is that shippers themselves search for other shippers with complementary demands. For example, a shipper with one-way demands between Chicago and St. Louis will search for a shipper with one-way demands between St. Louis and

${ }^{4}$ Links between productivity and the efficiency of the market clearing process exist in many markets, particularly those like trucking in which supply and demand are highly differentiated. Labor markets are good examples.

${ }^{5}$ Narrowly-defined markets tend to be illiquid, and matches in such markets may not improve much upon those achieved through decentralized matching. 
Chicago. However, much of the time complementary demands are identified by intermediaries, who add value by lowering search costs.

There are two main classes of intermediaries in trucking: for-hire carriers and brokers. They differ in whether they own trucks; for-hire carriers control truck fleets but brokers do not. As explained in Baker and Hubbard (2000b), truck ownership enhances intermediaries' incentives to find complementary hauls because it allows them to appropriate a greater share of the surplus. Most intermediaries in the industry are for-hire carriers. Shippers tend to use for-hire carriers when identifying complementary demands is important, such as for long or less-than-truckload hauls, and private fleets when it is not.

Shippers and carriers sometimes contract ahead for service. These contracts usually cover a series of recurring hauls. Arrangements of this sort reduce search costs by eliminating the need to search for trading partners recurrently, but tend to lower the short-term efficiency of the match between trucks and hauls. ${ }^{6}$ Hubbard (2001) shows that contracting becomes more prevalent relative to simple spot arrangements as local markets become thinner, particularly for long hauls. Shippers and carriers tend to rely on short term arrangements when they use non-specialized equipment for hauls on thick shipping lanes, but longer-term arrangements when they use specialized equipment or operate on thin shipping lanes. Capacity and demands tend to be matched over longer horizons for hauls involving specialized equipment than non-specialized equipment.

Both the presence of intermediaries and the fact that most intermediaries own trucks thus can be interpreted as institutional responses to the matching problem. The presence of intermediaries lowers search costs; truck ownership provides intermediaries strong incentives to find good matches. These institutional features increase capacity utilization and thus raise truck drivers' productivity.

\section{Dispatch and Information}

Operationally, the people most directly involved in matching capacity to demand are dispatchers. Dispatchers assign trucks and drivers to hauls. Dispatchers who manage shippers' private fleets primarily assign trucks to their internal customer's hauls. Those who manage for-hire

\footnotetext{
${ }^{6}$ They may also serve to lower hold-up risks, by protecting relationship-specific informational investments. See Hubbard (2001).
} 
carriers' fleets assign trucks to external customers' (shippers') hauls. Dispatchers sometimes actively search for additional hauls when doing so would increase capacity utilization, contacting shippers either directly or through brokers. ${ }^{7}$ For example, they try to find good "backhauls" (return trips) or, when trucks are partly empty, identify other hauls along the same route that would fill trucks. Such activities are more common for dispatchers managing for-hire than private fleets. But they are not unusual within private fleets, particularly in cases where shippers use private fleets for long hauls.

Dispatchers work in a highly dynamic environment. Assignments and schedules are not set far in advance, in large part because it is often hard to forecast exactly when individual shippers will demand service and exactly when particular trucks will come free. In practice, dispatchers assign trucks and drivers to a series of hauls at the beginning of the day or a shift. This is often a provisional schedule. They then update schedules throughout the day as situations warrant, rearranging assignments in response to unexpected delays and new service orders (some of which they may have actively solicited to fill capacity). Dispatchers who do this well increase the productivity of the trucks and drivers they manage.

Information is a critical input to dispatchers' decisions. In particular, knowing where trucks are and how full their trailers are lets dispatchers forecast better the time and location capacity will become available. Better forecasts, in turn, allow them to allocate trucks across existing orders and market spare capacity more efficiently. They also can provide customers better information about arrival times.

Information processing and communication capabilities are important as well, because they help dispatchers make good decisions and redirect drivers. Most dispatchers use route-planning software packages to help develop schedules. Many of these packages are relatively inexpensive and PC-based. Dispatchers commonly use the software to draft schedules, which they then revise to account for factors not accounted for by the software.

Communicating with drivers has traditionally been difficult when trucks operate outside radio

${ }^{7}$ At larger firms, different individuals assign trucks to hauls and solicit business. I will abstract from the fact that individuals specialize, assuming that they work closely enough together so that they can be considered one decision-making unit. 
range (about 25 miles). Dispatchers and drivers relied on a "check and call" system in which drivers stopped and called in every three to four hours. During the 1990s, declines in the price of longdistance cellular communication have led many dispatchers and drivers to abandon this system and communicate with cellular phones. This has significant advantages over the previous system because it allows dispatchers to initiate contact with distant drivers just like they do with those close by. Dispatchers no longer have wait until drivers call in to give them instructions, and drivers do not have to find a pay phone just to provide status reports and ask if there are schedule changes. Using cell phones alone has drawbacks, however. In particular, there remain significant coverage gaps, and information about trucks' location takes time to collect and is neither verifiable nor in electronically-processable form.

\section{On-Board Computers}

Two classes of OBCs began to diffuse in the trucking industry in the late 1980s: trip recorders and electronic vehicle management systems (EVMS).

Trip recorders are devices that monitor how drivers operate trucks. They record when trucks were turned on and off, trucks' speed over time, and incidents of hard braking. Trip recorders collect data onto a storage device. Dispatchers upload these data once drivers return to their base. The data trip recorders collect provide dispatchers verifiable information regarding drivers' activities, including whether they were speeding or took unauthorized breaks. Trip recorders also track how trucks' engines perform; for example, they track fault codes that result when engines work improperly. This information is useful to mechanics because it helps them diagnose engine problems better.

Trip recorders are thus useful for improving drivers' incentives and mechanics' maintenance decisions. They are not particularly useful for improving dispatchers' resource allocation decisions because they do not provide dispatchers information in a timely enough fashion.

EVMS are more advanced than trip recorders. They contain all trip recorders' capabilities. In addition, they record trucks' geographic location (for example, using satellite tracking) and provide a close-to-real time data connection between dispatchers and trucks. These additional capabilities help dispatchers make better scheduling decisions and communicate them quickly to drivers. Knowing exactly where trucks are helps dispatchers allocate trucks across existing service 
orders and market excess capacity better. The communication link helps them notify drivers of schedule changes quickly and effectively.

There is an important economic distinction between trip recorders and EVMS. Both classes of devices are useful for improving incentives and maintenance decisions. EVMS, however, is also useful for improving resource allocation decisions (“coordination”).

This paper focuses primarily on the impact of OBCs' coordination-improving capabilities on capacity utilization. ${ }^{8}$ There are two reasons for this.

First, evidence from the trade press and plant visits indicates that OBCs primarily affect capacity utilization though better dispatch, not through improvements in drivers' incentives or maintenance decisions. One exception to this is when drivers' jobs involve cargo handling as well as driving; some firms attribute productivity gains to the ability to track how long drivers spend at stops. Trucks can be utilized more intensively when drivers load and unload cargo faster. (See Baker and Hubbard (2000b).) OBC adoption also may have led some firms to provide drivers stronger fuel economy-based incentives, and this may have led to productivity gains, but there is little indication that these increases are substantial.

Second, it is difficult to isolate the impact of OBCs' incentive-improving capabilities, because all OBCs have both incentive- and maintenance-improving capabilities.

\section{Data}

The data are from the Bureau of the Census' 1992 and 1997 Truck Inventory and Use Surveys (TIUS). ${ }^{9}$ The TIUS is a mail-out survey taken every five years as part of the Census of Transportation. The Census takes a random sample of trucks from vehicle registration records, and sends their owners a questionnaire that asks them about the characteristics and use of their trucks. For example, questions ask respondents their trucks' make and model. Importantly for this study, the Survey asks whether trucks have trip recorders or EVMS installed. It also asks many questions

${ }^{8}$ Other papers (Baker and Hubbard (2000a, 2000b)) have examined the organizational implications of OBCs' incentive-improving capabilities.

${ }^{9}$ The 1997 Survey is actually called the Vehicle Inventory and Use Survey. See Bureau of the Census $(1995,2000)$ and Hubbard (2000) for more details about these Surveys. 
about how trucks were used during the previous year, including such things as whether it was owned by its driver, whether it operated within a private or for-hire fleet, how far from home it generally operated, what kind of trailer was attached, what classes of products it carried, and the state in which it was based. Although the TIUS contains observations of a wide variety of truck types, all of the analysis in this paper uses only observations of truck-tractors, the front halves of tractor-trailer combinations.

The Survey also asks several questions that elicit information regarding how intensively individual trucks were utilized. Answers to these questions provide the variables used to evaluate productivity. One question asks how many miles the truck was driven during the previous year. Other questions ask what fraction of miles the truck was driven without a trailer, and what fraction of miles it was driven empty. Combined with the number of miles the truck was driven, answers to these questions indicate the number of miles the truck was driven with cargo ("loaded miles"). The Survey also asks the weight of the truck when empty and the average weight of the truck plus cargo during a typical haul in the previous year. The difference between these figures is the average weight of the cargo the truck hauled ("cargo weight"). Multiplying loaded miles by cargo weight and dividing by 2000 gives an estimate of the truck's output during the previous year in ton-miles. Finally, these Surveys ask owners how many weeks out of the year trucks were in use. This is an important control variable. Its absence from previous Surveys is the reason I use only the 1992 and 1997 Surveys.

Responses to these questions likely overstate trucks' output and capacity utilization somewhat, although probably in a similar fashion from year to year. Cargo weight is probably overstated because respondents likely report cargo weight when trucks leave terminals, which is not the average amount of cargo in trucks' trailers while loaded when trucks deliver to multiple points. ${ }^{10}$ Respondents likely understate empty miles, particularly when trucks haul trailers for which backhauls are unlikely such as auto trailers. This is because respondents who do not try to find

${ }^{10}$ Mileage estimates from the VIUS are consistent with those from other sources, but tonmile estimates are not. This indicates that the cargo weight data in the VIUS are not very reliable. I therefore use loaded miles rather ton-miles as my main output measure in the analysis below. 
backhauls may not include backhaul capacity in the denominator of this fraction. But this bias works against finding relationships between OBC adoption and productivity increases if adoption leads firms to reconsider what they think of as unused capacity: for example, if it leads them to newly consider empty backhauls as empty miles.

The Survey therefore provides detailed information about production at the individual truck level. This level of disaggregation is rare, and provides a significant advantage in studying technology adoption, organizational structure, and productivity issues. ${ }^{11}$ The Survey does not, however, allow one to identify trucks' owners. It is therefore impossible to determine the for-hire or private fleet in which individual trucks operated. Although one can aggregate up to the industry or industry segment level, the data cannot be used to investigate productivity at the firm level.

The following subsection summarizes some basic patterns in the data.

\section{Simple Patterns}

Table 1 presents simple trends in several output measures. The top panel indicates that capacity utilization increased between 1992 and 1997. On average, miles per truck increased by $7.5 \%$, and loaded miles increased by $10.1 \%$. Although the cargo weight data in the VIUS are not very reliable, there is no indication that average cargo weight decreased during this time. Reports from these data indicate that it increased by $2.5 \%$, leading to a $12.5 \%$ increase in ton-miles per truck.

The bottom panel reports similar figures, averaging only over trucks that were in use at least 48 weeks out of the year. Comparing trends in these figures to those in the top panel indicates the extent to which increases in capacity utilization were due to increases in the number of weeks in service rather than increases in how intensively trucks were used conditional on weeks in service. The table indicates that ton-miles per truck actually increased slightly more within this subsample than among trucks at large. Loaded miles increased by $8.3 \%$ - somewhat less than the $10.1 \%$ increase within the full sample, but still a large increase. These figures do not suggest that increases in capacity utilization during this period were entirely due to the fact that economic growth led trucks to be in service more weeks out of the year in 1997 than 1992. Capacity utilization increased during this time even among the most-intensively-used trucks.

\footnotetext{
${ }^{11}$ The manufacturing equivalent perhaps would be to have data at the level of the production line rather than the establishment or firm.
} 
Figure 1 provides further evidence. This plots average weeks in use, by truck age, for the 1992 and 1997 samples. If increases in loaded miles reflect increases in the utilization of infrequently-used trucks, older trucks should be used more weeks in 1997 than 1992. Figure 1 indicates that while weeks in use declines steadily with truck age in both years, the plots track each other very closely. ${ }^{12}$ There is no evidence that older trucks were used more weeks per year in 1997 than 1992.

Figure 2 relates loaded miles per week to net EVMS adoption. The lines plot loaded miles per week as a function of age; the bars report net EVMS adoption between 1992 and 1997. There are three important facts. First, old trucks are used less intensively than new ones, even conditional on weeks in use. Second, the gap between 1997 and 1992 trucks is greater when comparing new trucks than old trucks. Once again the greatest increase in capacity utilization is for the trucks that are already utilized intensively. Third, the gap between the 1997 and 1992 trucks is widest where net adoption is highest - for one to five year old trucks. 1992-1996 model year trucks had much higher EVMS use rates in 1997 than 1987-1991 model year trucks did in 1992. Capacity utilization rates also appear to increase more for trucks in this range than younger or older trucks.

Combined, these tables provide evidence consistent with the hypothesis that EVMS adoption contributed to increases in capacity utilization. Capacity utilization increased the most for alreadyintensively-used trucks, and trucks for which EVMS tended to be adopted most had the greatest increases in capacity utilization.

Furthermore, additional evidence indicates that capacity utilization increases during this time also represent increases in labor productivity. Increases in loaded miles per truck would not reflect increases in labor productivity if the ratio between drivers and trucks changed, as would be the case if firms were using trucks (but not drivers) for double shifts more in 1997 than 1992. However, data from the October CPS indicates that the number of truck drivers increased by 26.8\% between 1992 and 1997; the 1997 VIUS indicates that the number of heavy duty trucks increased by $25.7 \%$. The change in the driver-truck ratio was negligible during this time.

The next section presents the empirical framework that I use to estimate OBCs' effect on

\footnotetext{
${ }^{12}$ The low figure for brand-new trucks reflects that many were put into service in the middle of the survey year.
} 
capacity utilization. Traditionally, information problems have limited how intensively trucks have been utilized, conditional on being in use during a period (e.g., a day or shift); hence, by mitigating these problems, OBCs can shift out trucks' per-period production frontier. Estimating this effect requires controlling for differences in the number of periods trucks with and without OBCs are used. One of the patterns in Figure 2 indicates that doing so is not a trivial exercise. All else equal, trucks' per-period frontier should not vary across vintages: conditional on being in use during a period, old trucks can be used about as intensively as new ones. Thus, the fact that loaded miles per week is lower for old trucks than new ones implies that simply normalizing loaded miles by how many weeks trucks are in use does not completely control for differences in how many periods trucks are in use. ${ }^{13}$ Much of the next section focuses on developing a more sophisticated way to utilize data on weeks in use to control for differences in periods in use.

\section{Empirical Framework}

Let $\mathrm{y}_{\mathrm{it}}{ }_{\mathrm{f}}$ equal the frontier production level, in loaded miles, of truck $\mathrm{i}$ in period t. Let $\mathrm{k}_{\mathrm{it}}$ be a dummy variable that equals one if truck $\mathrm{i}$ is in use in period $\mathrm{t}$ and zero otherwise. Assume that conditional on being in use, trucks are used at their frontier. The realized level of loaded miles of truck i over the course of $\mathrm{T}$ periods is thus:

$$
y_{i}^{1}=\sum_{t=1}^{T} y_{i t}^{f} k_{i t}
$$

Assume for simplicity that conditional on being in use, trucks' frontier production level is constant across periods, perhaps because they are used in similar ways from period to period, conditional on being in use. Then,

$$
y_{i}^{1}=y_{i}^{f} s_{i}
$$

where $s_{i}$ is the share of periods that truck $i$ is in use.

$\mathrm{y}_{\mathrm{i}}^{\mathrm{f}}$, truck i's frontier utilization rate, is influenced by many factors, including the characteristics of the hauls for which the truck is used, the characteristics of the shipper and carrier,

\footnotetext{
${ }^{13}$ Although Table 2 shows unconditional differences, these differences remain economically and statistically significant when including controls for how trucks are used.
} 
and the informational environment. Whether trucks have OBCs may affect $\mathrm{y}_{\mathrm{i}}^{\mathrm{f}}$ by improving drivers' incentives or by improving dispatchers' knowledge and communication capabilities. The latter may facilitate better matches between trucks and hauls. I specify $\ln \mathrm{y}_{\mathrm{i}}^{\mathrm{f}}$ as:

$$
\ln y_{i}^{f}=X_{i} \beta+\delta_{1} D_{i}+\varepsilon_{1 i}
$$

where $X_{i}$ includes observable haul and firm characteristics that affect trucks' frontier and $D_{i}$ is a vector of dummies that reflect whether and what kind of OBCs are installed on truck i. $\epsilon_{1 \mathrm{i}}$ captures the effect of unobserved haul, truck, and firm characteristics.

I next discuss $\mathrm{s}_{\mathrm{i}}$. Suppose that at the start of each period, dispatchers observe some information about the level and composition of demand, and match trucks to hauls (at least provisionally) on the basis of this information. When capacity exceeds forecasted demand levels, not all trucks will be put into service. $\mathrm{k}_{\mathrm{it}}$ will thus vary with demand and with truck characteristics. It will be more likely to be one when demand is high. If dispatchers choose to use their best trucks when capacity exceeds demand, it will tend to be higher for newer, better-equipped trucks conditional on demand levels; thus, it will be more likely to equal one when trucks are new or have OBCs installed. $\mathrm{k}_{\mathrm{it}}$ may also vary with firm characteristics. All else equal, if a firm is less able to find hauls for a truck, the truck will be more likely to be idled. If firms lease their marginal trucks, however, this will mitigate the correlation between firm characteristics and $\mathrm{k}_{\mathrm{it}}$.

I assume that $\mathrm{s}_{\mathrm{i}}$ is related to demand, truck, and firm characteristics by the following reducedform equation.

$$
\ln s_{i}=Z_{i} \gamma+\delta_{2} D_{i}+\varepsilon_{2 i}
$$

$\mathrm{Z}_{\mathrm{i}}$ includes demand and firm characteristics that are correlated with the share of periods trucks are in use. These may include variables that are also in $\mathrm{X}_{\mathrm{i}}$. One variable that I will assume to be part of $Z_{\mathrm{i}}$ but not $\mathrm{X}_{\mathrm{i}}$ is truck age: truck age influences whether dispatchers choose to use them when capacity exceeds demand, but does not affect how intensively they can be used in any particular period. $\mathrm{D}_{\mathrm{i}}$ is as above. $\delta_{2}$ captures correlations between $\mathrm{OBC}$ use and the share of periods truck $\mathrm{i}$ is in use. Such correlations could arise either because OBC use causes the share of periods to be higher (dispatchers idle trucks with OBCs less) or because when firm or demand characteristics cause $\mathrm{s}_{\mathrm{i}}$ to be high, $\mathrm{OBC}$ use is higher (the returns to adoption are higher when demand is 
consistently high). $\epsilon_{2 \mathrm{i}}$ is a residual, and represents relationships between $\mathrm{s}_{\mathrm{i}}$ and unobserved factors that are orthogonal to both $Z_{i}$ and $D_{i}$. Since this is a reduced form, by construction, $E\left(e_{2 i} \mid Z_{i}, D_{i}\right)=$ 0 .

Taking logs of equation (2) and substituting in equations (3) and (4), I obtain:

$$
\ln y_{i}^{1}=X_{i} \beta+Z_{i} \gamma+\left(\delta_{1}+\delta_{2}\right) D_{i}+\varepsilon_{1 i}+\varepsilon_{2 i}
$$

This equation relates loaded miles to $\mathrm{OBC}$ use. The empirical goal is to estimate OBCs' effect on capacity utilization, $\delta_{1}$. However, as this equation shows, even if the orthogonality condition $\mathrm{E}\left(\epsilon_{1 \mathrm{il}} \mid \mathrm{D}_{\mathrm{i}}\right)$ holds, OLS estimates of loaded miles on OBC use reflect both OBCs' effect on capacity utilization and correlations between $\mathrm{OBC}$ use and the share of periods trucks are in use. I next discuss a method to estimate $\delta_{1}$ that exploits the fact that the data contain information on the share of weeks trucks are in use. Thereafter I discuss the orthogonality condition, and interpretations of the OLS estimate when OBCs' effect on $y_{i}^{f}$ differs across hauls.

Let $\mathrm{y}_{\mathrm{i} 2}$ equal the share of weeks truck $\mathrm{i}$ is in use over the course of $\mathrm{T}$ periods, and specify:

$$
y_{i}^{2}=s_{i}^{\lambda} h_{i}
$$

$\lambda$ is the elasticity between the share of weeks in use and the share of shifts in use. Trucks that are used a higher fraction of shifts will also tend to be used more weeks per year. $h_{i}$ includes factors that affect the number of weeks in use, conditional on the number of shifts in use. $h_{i}$ would be higher when demands for the truck are more cyclical: for example, trucks that primarily haul agricultural goods tend to be used a low number of weeks relative to shifts because demand comes in spurts. Assuming that $\ln \mathrm{h}_{\mathrm{i}}=\mathrm{W}_{\mathrm{i}} \alpha+\epsilon_{3 \mathrm{i}}$, I therefore have the following:

$$
\begin{aligned}
& \ln y_{i}^{1}=X_{i} \beta+Z_{i} \gamma+\left(\delta_{1}+\delta_{2}\right) D_{i}+\varepsilon_{1 i}+\varepsilon_{2 i} \\
& \ln y_{i}^{2}=W_{i} \alpha+\lambda Z_{i} \gamma+\lambda \delta_{2} D_{i}+\varepsilon_{3 i}+\lambda \varepsilon_{2 i}
\end{aligned}
$$

$\delta_{1}$ and $\delta_{2}$ are now separately identified. The logic is that if trucks with OBCs are used more weeks than those without them, this should reflect differences in the number of periods trucks with and without $\mathrm{OBCs}$ are used, but not differences in per-period production frontiers. One can thus use this information to back out how much relationships between loaded miles and $\mathrm{OBC}$ use reflect differences in production frontiers. Doing so is simple if increasing the number of periods trucks are 
used increases loaded miles and weeks in use by the same percentage: if $\lambda=1$, subtracting the second equation from the first differences out $\delta_{2} \mathrm{D}_{\mathrm{i}}$. Alternatively, one can estimate $\lambda$; this requires having at least one variable that is related to the share of periods trucks operate but does not affect per-period production frontiers. I assume this to be the case for vehicle age, and estimate $\lambda$ from the ratio of the relationships between age and the two dependent variables.

The intuition is the following. Suppose there are two truck vintages: young and old. Suppose young trucks are used 10\% more weeks, but have $20 \%$ more loaded miles, than old ones. Suppose that trucks with OBCs are used 10\% more weeks then those without them, but have 25\% more loaded miles. Then the estimate of $\delta_{1}$ will indicate that OBCs caused capacity utilization to increase by $5 \%$.

The orthogonality condition $\mathrm{E}\left(\epsilon_{1 \mathrm{i}} \mid \mathrm{D}_{\mathrm{i}}\right)$ implies that unobserved haul characteristics that affect trucks' per-period frontier are independent of OBC use. This would be violated if, for example, some shippers are more sophisticated than others, and sophisticated shippers both are able to unload trucks faster because of better handling methods and value using carriers with OBC-equipped trucks. If so, then cross-sectional correlations between $\mathrm{OBC}$ use and loaded miles per week may reflect this omitted factor - shipper sophistication - rather than a causal relationship. Unlike the class of problems described above, this omitted factor is unlikely to affect how many weeks trucks are used so the correction procedure above does not apply.

One can examine this factor's relevance in a simple manner. Shippers' organizational sophistication likely differs across products - it tends to be higher for goods delivered to manufacturing or warehouse facilities than for those delivered to raw input processors or retail outlets. If this is true, the OBC coefficients should decrease when including a set of dummy variables indicating the product trucks haul. If the OBC coefficients are similar with and without this additional vector of controls, this is evidence against the relevance of this alternative hypothesis.

An alternative way of accounting for the prospect that the coefficients from cross-sectional regressions reflect omitted variables correlated with both $\mathrm{OBC}$ use and frontier is to exploit the time series dimension of the data. I have multiple cross-sections of data, and can examine relationships between changes in loaded miles and changes in OBC use using truck cohorts rather than trucks as the unit of observation. However, this would require restricting OBCs' effect on capacity utilization 
to be the same across years. The cross-sectional results presented below strongly suggest that such a restriction would be inappropriate. I therefore rely on identification strategies that exploit crosssectional rather than time variation in the data. ${ }^{14}$

As noted above, equation (3) assumes away unobserved heterogeneity in $\mathrm{OBCs}$ ' impact on capacity utilization. In fact, $\mathrm{OBCs}$ are likely to affect $\mathrm{y}_{\mathrm{i}}^{\mathrm{f}}$ differently across different hauls. A more general specification is:

$$
\begin{aligned}
\ln y_{i}^{f} & =X_{i} \beta+\delta_{1 i} D_{i}+\varepsilon_{1 i} \\
& =X_{i} \beta+\left(\delta_{1}+\psi_{i}\right) D_{i}+\varepsilon_{1 i}
\end{aligned}
$$

Here the marginal impact of OBCs on capacity utilization varies with omitted factors. Standard selection issues arise. OLS estimates of $\delta_{1}$, OBCs' average effect on capacity utilization across the entire sample, are biased.

$$
\hat{\delta}_{1, o l s}=\delta_{1}+E\left(\psi_{i} \mid D_{i}=1\right)
$$

This equation illuminates the information contained in the OLS estimate of $\delta$. The OLS estimate overstates the average effect of OBCs across the entire sample (assuming a positive correlation between $\mathrm{OBC}$ use and $\psi_{\mathrm{i}}$ ). But it captures the average effect of OBCs among adopters - the average effect of treatment on the treated. In an environment where selection of this sort is a problem, positive estimates of the OBC coefficients do provide evidence that OBCs increase capacity utilization for adopters - and are thus evidence of relationships between IT adoption and productivity increases.

The goal of the empirical work is to estimate $\mathrm{OBCs}$ ' realized impact on capacity utilization, rather than what its impact would be if OBCs were installed on all trucks. Thus, the results section emphasizes estimates of the effect of the treatment on the treated rather than trucks in general. The

\footnotetext{
${ }^{14}$ Furthermore, using a cohort-based strategy has the drawback of sharply reducing the number of observations in the data from the number of trucks to the number of cohorts. I have estimated cohort-based specifications of the basic model, and have found the coefficient estimates to be very noisy.
} 
results do, however, shed some indirect evidence on OBCs' impact on the average truck as of $1997 .^{15}$ The estimates will indicate considerable heterogeneity in the returns to adoption among adopters; in fact, I will find no evidence that the average capacity utilization benefits among adopters are positive within some segments. The fact that these benefits appear small or non-existent among many adopters suggests that they were probably very small among non-adopters as well, especially inframarginal non-adopters. Only about 35\% of trucks had OBCs as of 1997; hence, OBCs' capacity utilization benefits were probably close to zero for the average truck at this time.

\section{Results}

\section{Simple Cross-Sectional Regressions}

Table 2 presents results from univariate cross-sectional regressions that take the form of equation (5). ${ }^{16}$ I present these as preliminary to the main results below. The dependent variable is loaded miles. The vector $\mathrm{X}_{\mathrm{it}}$ contains a set of dummy variables that indicate how far from home the truck operated, a set of dummies that indicate what class of trailer was commonly attached to the truck, and dummies that indicate whether trucks were part of private fleets, used for contract carriage, were driven by owner-operators (and if so whether they were operating under long-term arrangements with larger trucking firms), and whether trucks were used to haul "less-than-truckload" shipments. The vector $Z_{i t}$ consists of a vector of dummy variables that characterize the truck's vintage. The coefficients of interest are those on OBC and EVMS, which correspond to $\left(\delta_{1}+\delta_{2}\right)$. $\mathrm{OBC}$ is the coefficient on a dummy that equals one if the truck had either a trip recorder or EVMS installed and zero otherwise; EVMS is that on a dummy that equals one if the truck had EVMS installed and zero otherwise. OBC reflects the correlation between trip recorder use and loaded miles; EVMS reflects the difference in loaded miles for trucks with EVMS and trucks with trip recorders. Thus, OBC picks up relationships between loaded miles and OBCs' incentive- and

\footnotetext{
${ }^{15}$ Attempts to estimate the average benefits across all trucks using standard sample selection procedures have produced noisy, non-robust estimates. While variables that affect OBCs' value in satisfying regulatory requirements but not the frontier - for example, proxies for how frequently trucks cross state boundaries - are generally statistically significant, they do not shift adoption strongly enough to identify OBCs' average effect on loaded miles.

${ }^{16}$ The sample size is lower here than in the previous tables because some observations have missing values for weeks in use.
} 
maintenance-improving capabilities and EVMS picks up those between loaded miles and OBCs' coordination-improving capabilities.

The upper panel contains results using the 1992 data. The first two columns use the entire sample; the first restricts all coefficients other than OBC and EVMS to zero, the second estimates the $\mathrm{X}_{\mathrm{it}}$ coefficients but not the $\mathrm{Z}_{\mathrm{it}}$ coefficients, and the third estimates all of the coefficients. From the first column, trucks with trip recorders had $45 \%$ more loaded miles than those without any IT. Trucks with EVMS had about 29\% more than those with trip recorders. These estimates decrease sharply when including the controls, and the r-squared increases from 0.04 to 0.48 . OBC remains positive and significant, and indicates that controlling for trucks' age and haul characteristics, trucks with trip recorders had $13.3 \%$ more loaded miles than those without them, and trucks with EVMS had $7.8 \%$ fewer loaded miles than those with trip recorders.

The lower panel reports analogous estimates using the 1997 data. The general patterns are similar to the 1992 data. The estimates in the third column imply that trucks with trip recorders had $7.6 \%$ more loaded miles than those without them, and that there is no significant difference in loaded miles between trucks with trip recorders and trucks with EVMS.

Estimates from these simple specifications indicate relationships between $\mathrm{OBC}$ use and loaded miles, but do not distinguish between OBCs' effect on capacity utilization and correlations that are due to differences in the share of periods trucks are used. The next subsection reports estimates from multivariate regressions that do so.

\section{Multivariate Regressions}

Table 3 presents GLS estimates of equations (7). $X_{i t}$ is the same as above. $Z_{i t}$ includes all of the variables in $\mathrm{X}_{\mathrm{it}}$, plus a full set of truck vintage dummies: if newer trucks are used more weeks per year than older trucks, this reflects dispatchers' (or the market's) choice of which trucks to use when demand is low. ${ }^{17} \mathrm{~W}_{\mathrm{it}}$ includes other variables that correlate with the cyclicality of individual trucks' use: dummies that indicate whether the truck was primarily used to haul fresh farm products

\footnotetext{
${ }^{17}$ Estimates of $\delta_{1}$ are robust to excluding variables in $\mathrm{X}_{\mathrm{it}}$ from $\mathrm{Z}_{\mathrm{it}}$, in large part doing so does not change which variables are included as controls in the loaded miles equation. See Table A1 in the Appendix for the full set of coefficients from the specifications reported in the first two columns of Tables 3 .
} 
and live animals. Trucks used to haul these goods are used far fewer weeks per year than other goods. ${ }^{18}$

The first column of Table 3 contains results using the 1997 data. OBC1 and EVMS1 are estimates of $\delta_{1}$, and reflect relationships between OBC use and $\mathrm{y}_{\mathrm{i}}{ }^{\mathrm{f}}$. OBC1 is small and not statistically significantly different from zero; this estimate provides no evidence that OBCs' incentive-improving capabilities affect capacity utilization. EVMS1 is positive and significant, indicating that $\mathrm{OBCs}$ ' coordination-improving capabilities do so. The point estimate indicates that, controlling for differences in the number of periods differently-equipped trucks are used, trucks with EVMS have 10.4\% greater loaded miles per week than those with trip recorders. This is an estimate of the average impact of EVMS' coordination-improving capabilities on capacity utilization among adopters as of 1997. The sum of OBC1 and EVMS1 is 0.127 with a standard error of 0.018 . This gives a point estimate of EVMS' total impact on capacity utilization, averaged across adopters: $12.7 \%$.

Moving down the table, OBC2 and EVMS2 are estimates of $\delta_{2}$. These reflect relationships between $\mathrm{OBC}$ use and periods in use. ${ }^{19} \mathrm{OBC} 2$ is positive and EVMS2 is negative. The former is statistically significantly different from zero using a t-test of size 0.15 ; the latter is significant using one of size 0.05 . The point estimates indicate that, holding constant truck vintage and other controls, trucks with trip recorders are used 5.6\% more periods than trucks without OBCs and 7.8\% more weeks than trucks with EVMS. One interpretation of this is that trip recorders tend to be used for hauls with regular schedules, and these hauls tend not to be cyclical. The sum of OBC2 and EVMS2 is not significantly different from zero, implying that trucks with EVMS are used almost exactly the same number of weeks on the average as trucks without OBCs. While usage rates appear high for

\footnotetext{
${ }^{18}$ Preliminary regressions indicated that these variables were correlated with number of weeks in use. The fact that these variables have explanatory power at all is interesting, considering that the unit of observation is a truck-tractor, and truck-tractors are highly mobile and are not specific to firms, trailers, or products outside of the short run. That haul characteristics are significant is evidence of frictions in shifting trucks across uses when demand is low for what they generally haul.

${ }^{19}$ Multiplying these by the estimate of lambda provides estimates of relationships between OBC use and weeks in use.
} 
trucks with trip recorders, they are not for trucks with EVMS. The correction procedure therefore mostly adjusts for differences in usage rates between trucks with trip recorders and the other categories, not between trucks without OBCs and with EVMS.

The estimate of $\lambda$ indicates that doubling the share of periods a truck is in use increases the share of weeks it is in use by about $40 \%$. In specifications not shown here, I have estimated the model holding $\lambda$ constant at values between 0.3 and 0.5 - a range 20 times the standard error - and find that the estimates of $\mathrm{OBC} 1$ and EVMS1 are stable within this range.

The bottom of the table reports estimates of $\mathrm{OBC} 1$ and EVMS1 from univariate regressions that do not use information from the weeks in use regression. Comparing these results to those in the multivariate specifications allows one to observe the effect of the correction. The coefficient on $\mathrm{OBC} 1$ is much higher and statistically significant; that on EVMS2 is much lower and not statistically significant. Ignoring the fact that the trucks with trip recorders are used more periods than other trucks leads one to overstate OBCs' incentive benefits and understate their coordination benefits.

The second column analogous results using the 1992 data. The estimates of OBC1, EVMS1, and $(\mathrm{OBC} 1+\mathrm{EVMS} 1)$ are all small and not statistically significant. These estimates provide no evidence that OBCs increased capacity utilization among adopters as of 1992. The estimates of OBC2 and EVMS2 show similar patterns to 1997, but are greater in absolute value. They indicate that trucks with trip recorders were used $14.4 \%$ more periods than those without OBCs and $10.0 \%$ more than those with EVMS. As before, the estimates at the bottom of the table indicate that, as in 1992, ignoring differences in usage rates leads one to overstate relationships between trip recorder use and loaded miles per week, and thus understate OBCs' coordination-related effect on capacity utilization. ${ }^{20}$

The other two columns report estimates from specifications that include a full set of product dummies in $\mathrm{X}_{\mathrm{it}}$. The coefficients on the product dummies themselves, not reported here, are jointly

${ }^{20}$ See Table A1 in the Appendix for the full set of coefficients from the specifications reported in the first columns of Tables 4 and 5. 
significant; this provides evidence that trucks' frontier varies with the products they haul. ${ }^{21}$ However, the estimates of OBC1 and EVMS1 are almost exactly the same as in columns on the left. This comparison suggests that the $\mathrm{OBC} 1$ and EVMS1 estimates in the left column do not reflect the effect of omitted variables such as shipper sophistication that could affect both OBC use and trucks' frontier independently. If they did, one would expect OBC1 and EVMS1 to decrease when including the product dummies.

Together, these regressions provide evidence that $\mathrm{OBC}$ adoption has increased capacity utilization in trucking through better resource allocation decisions. Taking the coefficients as point estimates of the benefits to adopters, EVMS increased capacity utilization among adopters by an average of $12.7 \%$. Using the means in Table 1, this translates to about 8200 more loaded miles per truck per year: about one more medium-distance haul per week. Alternatively, one can think of this as about five fewer hours per 40-hour week of empty or idle time. Most of this increase was due to EVMS' coordination-improving capabilities; point estimates indicate that they increased capacity utilization among adopters by an average of 10\%. There is no evidence of OBC-related capacity utilization increases as of 1992. The fact that the average returns among adopters increase over time is inconsistent with a simple "moving down the demand curve" diffusion story where the highest return adopters adopt first and appropriate the benefits instantaneously, but consistent with interpretations where the benefits of adoption come with a lag. One possible reason for this lag is that dispatching software improved throughout the 1990s. OBCs may have enabled greater capacity utilization gains as this software became more refined and integrated with carriers' operations. ${ }^{22}$

In contrast, Table 3 provides no evidence that $\mathrm{OBCs}$ ' incentive- and maintenance-improving capabilities have enabled adopters to achieve higher capacity utilization. Trucks with trip recorders do have higher loaded miles per week than those without them, but this appears to be due mainly to differences in their usage rates - possibly due to the regularity of the hauls - rather than the effects of technology.

${ }^{21}$ In general, they tend to be higher for raw materials than manufactured goods, possibly reflecting differences in the speed with which cargo can be loaded and unloaded.

${ }^{22}$ See Bresnahan and Greenstein (1996) for a general discussion of lags in the returns to adoption and complementary technological change. 


\section{Heterogeneity in the Returns to Adoption}

Table 4 reports 1997 estimates from analogous specifications that allow the OBC and EVMS coefficients to vary across twelve cells. These cells are distance/trailer/contractual form permutations; each coefficient therefore reflects a three-way interaction. Short haul trucks include those that generally operate less than 50 miles from their base; long hauls trucks are those that generally operate more than 50 miles from home. ${ }^{23}$ These estimates provide evidence regarding whether the returns to adopters vary in the sample according to variables I observe. The left panel reports a specification where I estimate all of the model's coefficients; the right panel reports results when I restrict all of the $\mathrm{OBC} 1$ coefficients to zero.

The table shows two general patterns. First, with the possible exception of the common/not van/long cell, there is little evidence that OBCs' incentive-improving capabilities lead to increases in capacity utilization. None of the $\mathrm{OBC} 1$ coefficients are statistically significantly different from zero. Furthermore, one can reject the null that the $\mathrm{OBC} 1$ coefficients are jointly equal to zero using a likelihood ratio test of size 0.05 .

Second, the estimates indicate considerable heterogeneity in the extent to which OBCs' coordination-improving capabilities increase capacity utilization. The EVMS1 coefficients are statistically significantly different across cells, indicating heterogeneity in the average returns to adopters. In the right panel, the coefficient on EVMS1 is positive and significant for all of the common carriage cells except for the short/not van one. The coefficient in the common/van/long cell indicates that, controlling for differences in periods in use, the average adopter in this cell has $22.8 \%$ more loaded miles than the average non-adopter. The point estimate for the average return to adopters is even higher in the common/van/short cell (36.4\%), and lower in the common/not van/long cell $(11.6 \%)$, though the differences are not statistically significant. ${ }^{24}$ The cross-cell

\footnotetext{
${ }^{23}$ I have estimated the models dividing the long haul cells more finely. The results are similar to those below.

${ }^{24}$ One should attribute this latter result to coordination-related gains with caution, since the $\mathrm{OBC} 1$ coefficient in the left panel is nearly statistically significant for this cell. This is the cell in which there is the strongest evidence that capacity utilization increases reflect incentive improvements.
} 
patterns are similar when considering the private carriage cells, and one cannot reject the null hypothesis that the coefficients in the private carriage cells are the same as their counterparts in the common carriage cells. This suggests that the adopters in these different governance forms face similar short-run problems in utilizing their fleets' capacity. ${ }^{25}$ In contrast, there is less evidence of capacity utilization increases in the contract carriage cells. The coefficient on EVMS1 is positive and significant only in the contract/van/long cell, and the coefficient in this cell is statistically significantly lower than its counterpart in the common/van/long cell. This is unsurprising; contract carriage arrangements tend to be used when shippers have demands for a series of regularlyscheduled hauls. Backhauls can be arranged far in advance for the bulk of these hauls, and knowing where trucks are in real time may not improve matches much. Adoption takes place in these cells, but more of the benefits probably come in ways other than truck utilization; for example, it may enable shippers' customers to allocate resources better by helping them track and anticipate deliveries.

Table 5 explores the distribution of EVMS-related capacity utilization increases. The first row reports the estimate of $(\mathrm{OBC} 1+\mathrm{EVMS} 1)$ from the first column in Table $3(0.127)$, followed by several calculations. Reading across, the "all trucks" cell is $100 \%$ of the industry, EVMS adoption in this cell is $25.6 \%$, and adopters in this cell make up $25.6 \%$ of the industry. Taking $12.7 \%$ as the average capacity utilization increase among adopters in the industry, these imply that EVMS use by adopters in this (universal) cell increased capacity utilization by $3.3 \%$ in the industry. This is an estimate of advanced OBCs' effect on capacity utilization in the industry as of 1997.

The rest of the rows use the estimates from the right panel of Table 5 to investigate how the $3.3 \%$ capacity utilization increase splits across trailer/distance/contractual form cells. For example, the EVMS1 coefficient in the private/van/short cell is 0.404 . This cell made up $2.7 \%$ of the industry and adoption was $15.1 \%$ in this cell. Thus adopters in this cell made up $0.4 \%$ of the industry and on the average increased capacity utilization by $40.4 \%$. Adoption within this cell increased capacity

\footnotetext{
${ }^{25}$ The fact that the average returns to private fleet adopters are similar to those of "common carriage" adopters does not imply anything about the relative returns to non-adopters. The returns to adoption among non-adopting private fleets may be lower than non-adopting forhire ones, as would be the case if non-adopting private fleets tend to be those that are restricted to serve only internal customers.
} 
utilization in the industry by $0.17 \%(0.404 * 0.004)$, which is $4.8 \%$ of the industry total. Although the average returns among adopters are high within this cell, there are so few adopters in this cell that it contributes a small amount to the overall capacity utilization increase.

The main result from this table is that the distribution of IT-related productivity increases appears highly skewed. Only $5.5 \%$ of the trucks in the industry - adopters in the common/van/long cell - account for about $36 \%$ of the capacity utilization increase. ${ }^{26}$ Approximately another $37 \%$ comes from the other two long haul van cells. Thus, about $15 \%$ of the U.S. fleet accounts for about $73 \%$ of the benefit. More than half of the rest comes from adopters in the long haul non-van cells. How Much of the Increase in Capacity Utilization Between 1992 and 1997 Was EVMS-Related?

The estimates in Table 3 imply that EVMS enabled increases in capacity utilization of the U.S. tractor-trailer fleet of $3.3 \%$ in 1997 . In contrast, there is no evidence that they led to significant increases in capacity utilization as of 1992 . Table 1 reported that loaded miles per truck increased by $10.1 \%$ between 1992 and 1997 . The point estimates in this paper suggest that about $33 \%$ of this increase $(3.3 \% / 10.1 \%)$ was related to the growing use of on-board computers to achieve better matches between trucks and hauls. A substantial part of the rest is likely due to the expansion of the economy during this time.

This estimate of 33\% should probably be considered an upper bound, because EVMS use may have led to capacity utilization increases within certain segments as of 1992. Table A2 in the Appendix shows 1992 results from specifications analogous to Table 5. In the right panel, the estimates of EVMS1 are positive and significant for the private/not van/long and common/van/long cells. These point estimates indicate that adoption within these cells increased capacity utilization fleetwide by $0.4 \%{ }^{27}$ If one assumes that capacity utilization increases are zero in the rest of the cells, this would imply that about $29 \%((3.3 \%-0.4 \%) / 10.1 \%)$ of the capacity utilization increase

${ }^{26}$ For all rows save the first, column 6 equals column 5 divided by $3.48 \%$, which is the sum of the column 5 entries from the cells. This differs from $3.25 \%$, the estimate of industry capacity utilization gains from Table 4 , because the coefficient estimates in column 1 are from a different specification.

${ }^{27}$ Adopters within these two cells made up $0.88 \%$ and $4.01 \%$ of the fleet, respectively. $0.4 \%=(0.88 \% * 0.160+4.01 \% * 0.097)$ 
between 1992 and 1997 was due to EVMS-related improvements in resource allocation.

What Are the IT-Enabled Increases in Capacity Utilization Worth?

Trucking makes up a significant part of economy; thus, even small proportional increases in productivity imply large benefits in absolute terms. The American Trucking Associations estimates that trucking (including private fleets) was a $\$ 486$ billion industry in 1998 , or $6.1 \%$ of GDP. ${ }^{28}$ Operating margins are small in trucking; therefore, this is a rough approximation of costs. Multiplying \$486 billion by 3.3\% gives a back-of-the-envelope estimate of the value of OBC-related increases in capacity utilization: $\$ 16$ billion per year. This estimate does not account for productivity benefits other than in truck utilization, such as any benefits that accrue to shippers and receivers from being better able to anticipate trucks' arrivals. $\$ 16$ billion in annual benefits therefore may well be a conservative estimate for the general productivity gains associated with OBC use as of 1997.

These increases in capacity utilization have involved costs, but the costs are probably very small relative to the benefits. Although there are depreciation and labor costs from using trucks more intensively, these are probably quite small in many cases. For example, running trucks loaded rather than empty causes little extra depreciation, and does not require drivers to work more hours. Furthermore, the OBCs themselves are very inexpensive; the most popular EVMS costs users only $\$ 100$ per month per truck to lease, including messaging costs. While my point estimate of the average capacity utilization increase among adopters is 13\%, EVMS hardware and messaging costs increase operating costs by less than $1 \% .{ }^{29}$ Finally, while using OBCs effectively usually requires some complementary investments in human capital and back-office IT, it generally does not involve changes in dispatchers' or drivers' jobs that require significant amounts of training, and backoffice hardware and software is usually PC based and supplied by competitive firms. The net benefits

\footnotetext{
${ }^{28}$ American Trucking Associations (2000). I quote the estimate for 1998 because methodological changes and new data led this and other publications to substantially increase their estimate of the size of the industry, starting first with estimates for 1998. These methodological changes account for the fact, for example, that much of "rail" and "air" freight travels by truck for all or part of the way.

${ }^{29}$ Assuming operating costs of \$2/mile (American Trucking Associations (2000)) and 6,000 miles per truck per month, average monthly operating costs are on the order of $\$ 12,000$ per month.
} 
would be very high even if the amortized cost per truck of these complementary investments were five times hardware and messaging costs, and there is no indication from interviews and the trade press that the costs associated with such investments are nearly this large.

\section{Conclusion}

Technologies that collect and disseminate information play a unique role in the economy. As Hayek stated more than fifty years ago, such technologies increase productivity by improving decisions, in particular resource allocation decisions. This paper examines the impact of one such technology - on-board computers - on capacity utilization in the trucking industry. Preliminary evidence indicates that on-board computer use has increased capacity utilization significantly: in 1997, EVMS increased capacity utilization by $13 \%$ on adopting trucks. This increase appears to be mostly due to advanced capabilities that let dispatchers determine trucks' position in real time, and allow dispatchers and drivers to communicate while drivers are in their truck. These capabilities enable dispatchers and drivers to keep trucks on the road and loaded more.

On-board computers in trucking are among the first commercially-important applications of wireless networking technologies. Many other such applications are likely to follow in the near future, as companies are currently attempting to develop and commercialize wireless applications that work off a diverse set of hardware platforms, including cellular phones and handheld computers. The economic value of these applications is based on the same principle as OBCs: information improves decisions; communication enables decisions to be executed. This allows dispersed individuals to identify and avail themselves of economic opportunities. The estimates in this paper indicate that the productivity gains from such applications can be quite large. 


\section{References}

American Trucking Associations, American Trucking Trends 2000, Alexandria, Transport Topics Press, 2000.

Athey, Susan and Scott Stern, "The Impact of Information Technology on Emergency Health Outcomes," MIT, 2000.

Baker, George F., and Thomas N. Hubbard, "Contractibility and Asset Ownership: On-Board Computers and Governance in U.S. Trucking,” NBER Working Paper \#7634, April 2000(a).

Baker, George F., and Thomas N. Hubbard, "Make Versus Buy in Trucking: Asset Ownership, Job Design, and Information," September 2000(b).

Bresnahan, Timothy and Shane Greenstein, "Technical Progress and Co-invention in Computing and the Use of Computers," Brookings Papers on Economic Activity: Microeconomics 1996, 1-77.

Brynjolfsson, Erik and Lorin Hitt, "Paradox Lost? Firm-Level Evidence on the Returns to Information Systems Spending,” Management Science, April 1996, 541-58.

Brynjolfsson, Erik, and Lorin Hitt, "Beyond Computation: Information Technology, Organizational Transformation and Business Performance," Journal of Economic Perspectives, Fall 2000, 23-48.

Brynjolfsson, Erik, and Shinku Yang, "Information Technology and Productivity: A Review of the Literature," in Advances in Computers, Volume 43, Marvin Zelkowitz ed., Academic Press, 1996.

Bureau of the Census, Truck Inventory and Use Survey: 1992, G.P.O, Washington, 1995.

Bureau of the Census, Vehicle Inventory and Use Survey: 1997, G.P.O, Washington, 2000.

David, Paul A., "The Dynamo and the Computer: An Historical Perspective on the Modern Productivity Paradox," American Economic Review, May 2000, 355-361.

Gordon, Robert J., "Does the 'New Economy' Measure Up to the Great Inventions of the Past?" Journal of Economic Perspectives, Fall 2000, 49-74.

Hayek, F. A., "The Use of Knowledge in Society,” American Economic Review, September 1945, 519-530.

Hubbard, Thomas N., "The Demand for Monitoring Technologies: The Case of Trucking," Quarterly Journal of Economics, May 2000, 533-560.

Hubbard, Thomas N., "Contractual Form and Market Thickness in Trucking," Rand Journal of 
Economics, Summer 2001.

Lehr, William and Frank R. Lichtenberg, "Computer Use and Productivity Growth in U.S. Federal Government Agencies,” Journal of Industrial Economics, June 1998, 257-279.

Lichtenberg, Frank R., "The Output Contribution of Computer Equipment and Personnel: A FirmLevel Analysis," Economics of Innovation and Technology, 3(1995), 201-217.

Oliner, Stephen D., and Daniel E. Sichel, "The Resurgence of Growth in the Late 1990s: Is Information Technology the Story?” Journal of Economic Perspectives, Fall 2000, 3-22. 
Table 1

Truck Utilization - 1992, 1997

$\begin{array}{rccccccc}\text { All Trucks } & & \text { Miles } & \begin{array}{c}\text { Loaded } \\ \text { Miles }\end{array} & \begin{array}{c}\text { Fraction } \\ \text { w/Load }\end{array} & \begin{array}{c}\text { Cargo } \\ \text { Weight }\end{array} & \text { Ton-Miles } & \text { N } \\ 1992 & 65451 & 58559 & 0.882 & 38190 & 1178 & 36082 \\ 1997 & 70351 & 64500 & 0.904 & 39223 & 1325 & 23183 \\ & & & & & & \\ \text { Change } & 7.5 \% & 10.1 \% & 2.5 \% & 2.7 \% & 12.5 \% & \end{array}$

Trucks in use $>48$ weeks

$\begin{array}{rrrrrrr}1992 & 77764 & 69993 & 0.893 & 37890 & 1399 & 18683 \\ 1997 & 82488 & 75836 & 0.915 & 39602 & 1592 & 11376 \\ & & & & & & \\ \text { Change } & 6.1 \% & 8.3 \% & 2.5 \% & 4.5 \% & 13.8 \% & \end{array}$


Figure 1

Average Weeks In Use

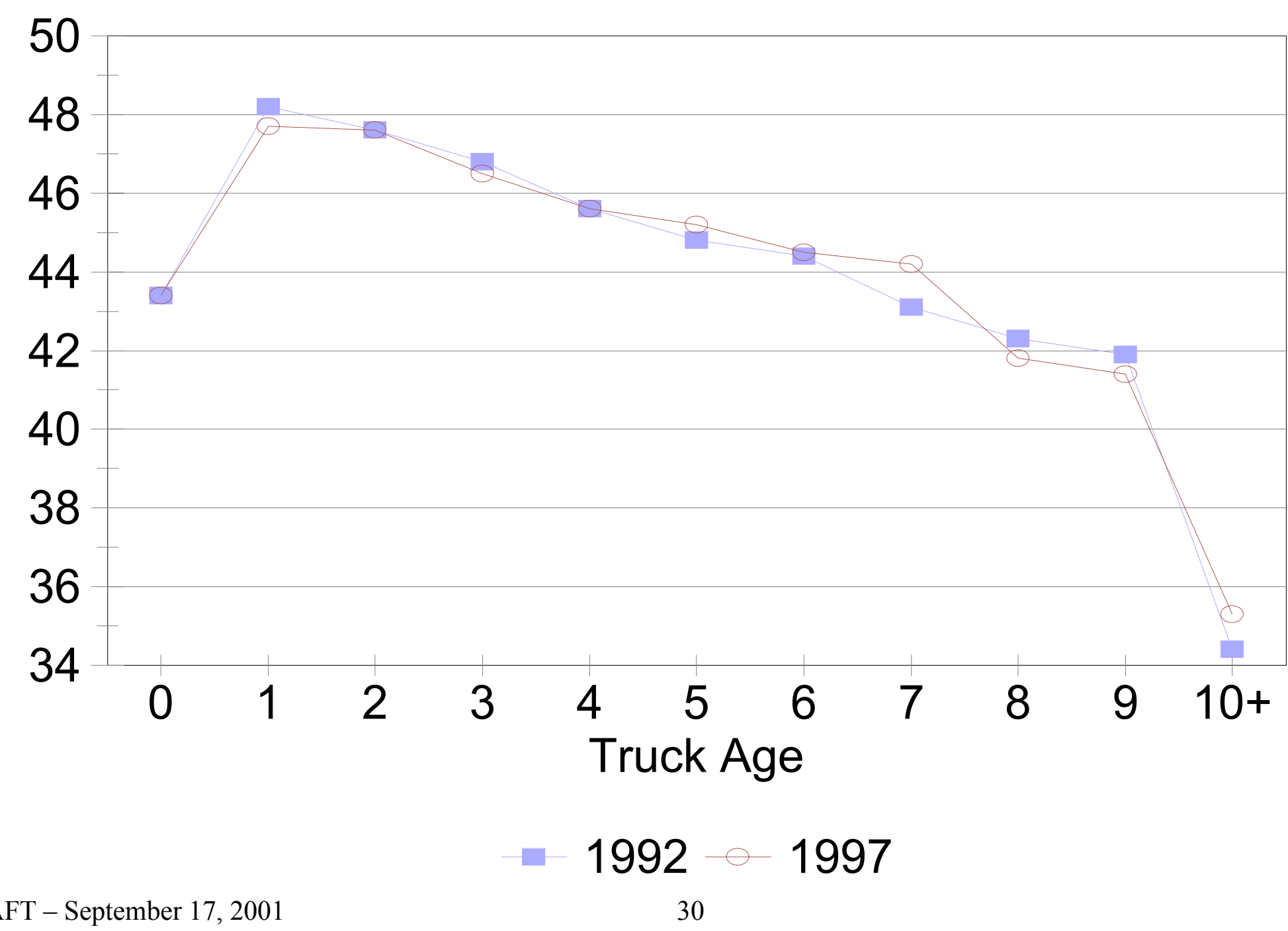


Figure 2

\section{Loaded Miles/Week, Net EVMS Adoption}

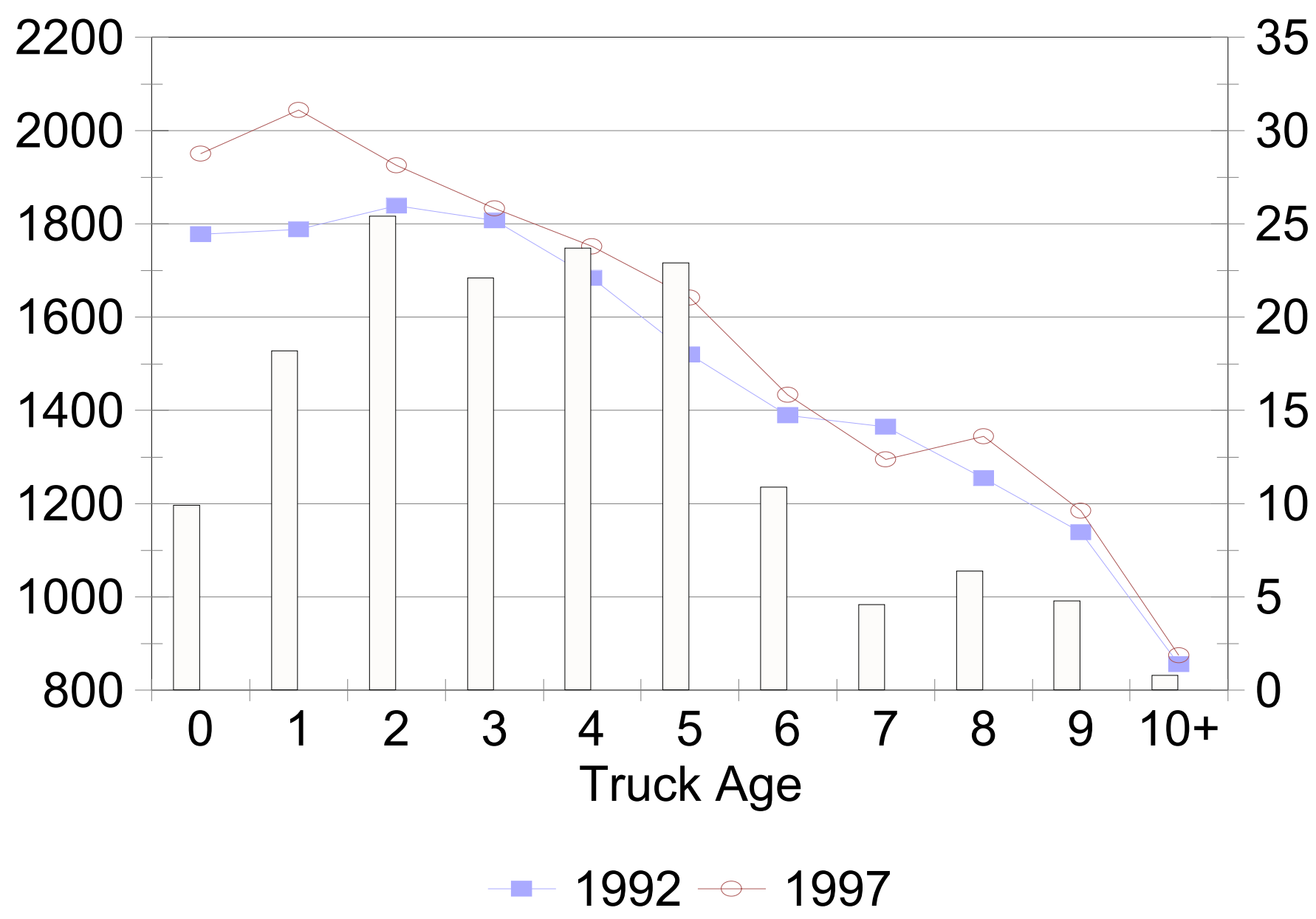




\section{Table 2}

\section{Cross-Sectional Regressions}

Dependent Variable: In(loaded miles)

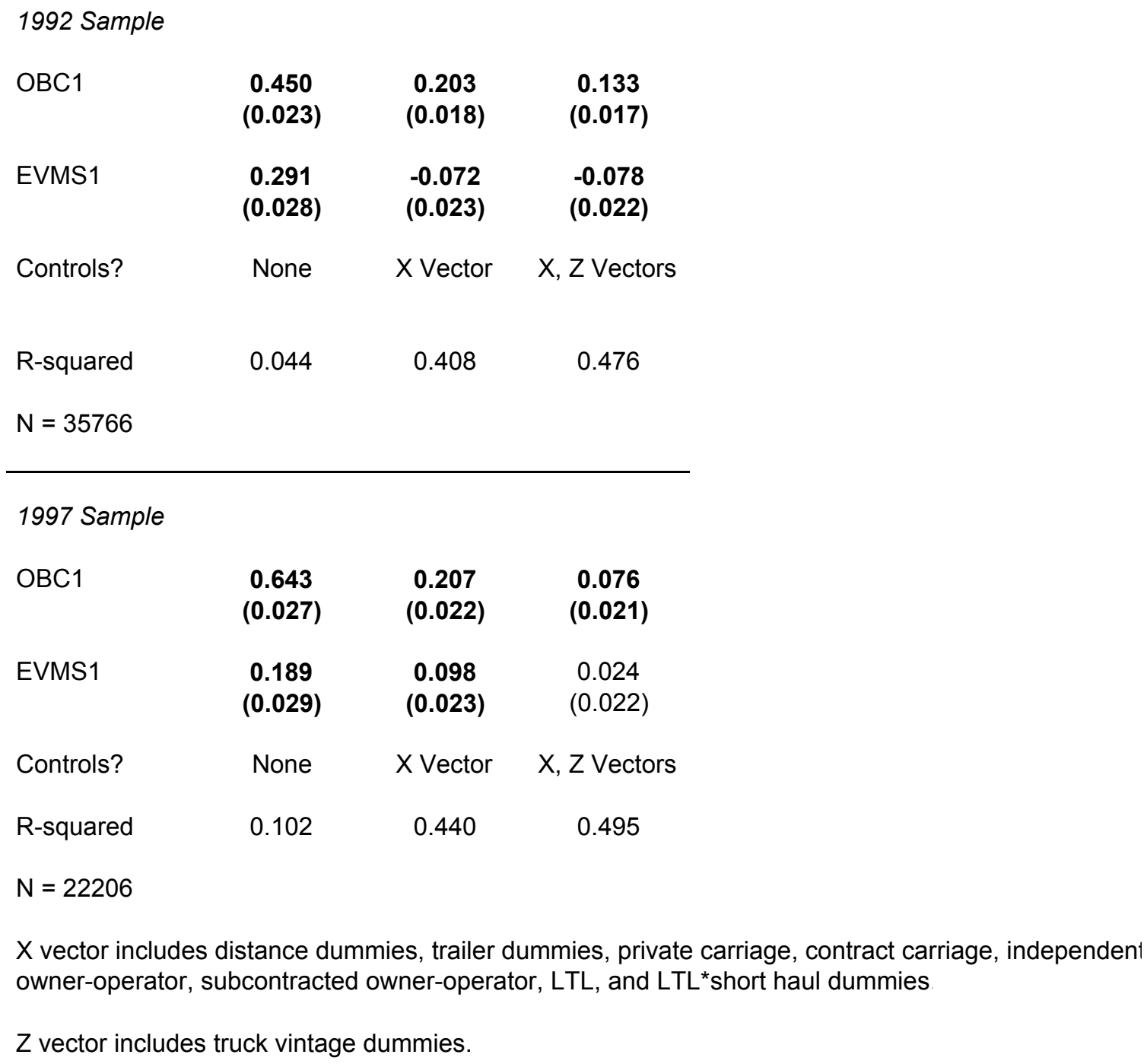




\section{Table 3 \\ Coefficient Estimates - Multivariate Regressions}

Dependent Variables: In(loaded miles), In(weeks in use)

$\begin{array}{lcccc}\text { Year } & 1997 & 1992 & 1997 & 1992 \\ & & & & \\ \text { OBC1 } & 0.023 & -0.011 & 0.024 & -0.009 \\ & (0.026) & (0.022) & (0.026) & (0.022) \\ \text { EVMS1 } & & & & \\ & \mathbf{0 . 1 0 4} & 0.022 & \mathbf{0 . 1 0 2} & 0.027 \\ & \mathbf{( 0 . 0 2 7 )} & (0.027) & \mathbf{( 0 . 0 2 8 )} & (0.026) \\ \text { OBC2 } & 0.056 & \mathbf{0 . 1 4 4} & 0.047 & \mathbf{0 . 1 3 7} \\ & (0.031) & \mathbf{( 0 . 0 2 5 )} & (0.030) & \mathbf{( 0 . 0 2 4 )} \\ \text { EVMS2 } & & & & \\ & \mathbf{- 0 . 0 7 8} & -\mathbf{0 . 1 0 0} & \mathbf{- 0 . 0 7 1} & \mathbf{- 0 . 0 9 6} \\ & \mathbf{( 0 . 0 3 2 )} & \mathbf{( 0 . 0 3 1 )} & \mathbf{( 0 . 0 3 2 )} & \mathbf{( 0 . 0 3 0 )} \\ & & & & \\ \text { Lambda } & \mathbf{0 . 4 0 6} & \mathbf{0 . 4 3 1} & \mathbf{0 . 4 1 0} & \mathbf{0 . 4 3 6} \\ & \mathbf{( 0 . 0 1 0 )} & \mathbf{( 0 . 0 0 8 )} & \mathbf{( 0 . 0 1 1 )} & \mathbf{( 0 . 0 0 8 )}\end{array}$

Dependent Variable: In(loaded miles)

$\begin{array}{lcccc}\text { OBC1 } & \mathbf{0 . 0 7 6} & \mathbf{0 . 1 3 3} & \mathbf{0 . 0 6 7} & \mathbf{0 . 1 2 8} \\ & \mathbf{( 0 . 0 2 1 )} & \mathbf{( 0 . 0 1 7 )} & \mathbf{( 0 . 0 2 1 )} & \mathbf{( 0 . 0 1 7 )} \\ \text { EVMS1 } & & & & \\ & 0.024 & \mathbf{- 0 . 0 7 8} & 0.028 & \mathbf{- 0 . 0 6 6} \\ \mathrm{N} & (0.022) & \mathbf{( 0 . 0 2 2 )} & (0.022) & \mathbf{( 0 . 0 2 2 )} \\ & & & & \\ & 22206 & 35766 & 22206 & 35766\end{array}$

Includes Product

$\mathrm{N} \quad \mathrm{N}$

Y $\quad Y$

Dummies in $\mathrm{X}$ ?

Bold indicates rejection of a two-tailed t-test of size 0.05 of $\mathrm{HO}$ : beta $=0$. 


\section{Table 4}

\section{Cross-Sectional Interactions - 1997}

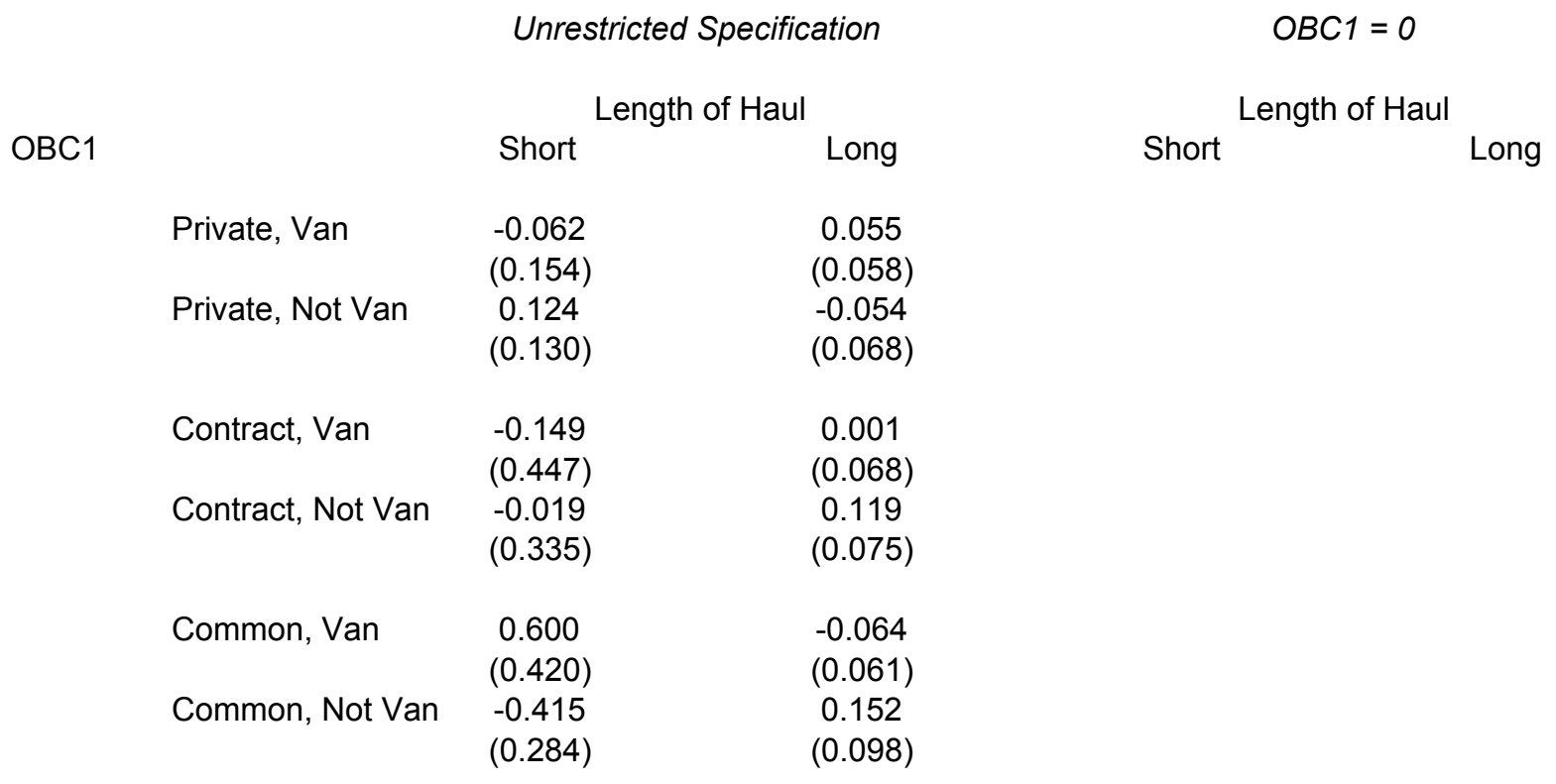

EVMS1

\begin{tabular}{|c|c|c|c|c|}
\hline Private, Van & $\begin{array}{c}0.462 \\
(0.183)\end{array}$ & $\begin{array}{c}0.116 \\
(0.063)\end{array}$ & $\begin{array}{c}0.404 \\
(0.123)\end{array}$ & $\begin{array}{c}0.161 \\
(0.041)\end{array}$ \\
\hline Private, Not Van & $\begin{array}{l}-0.081 \\
(0.151)\end{array}$ & $\begin{array}{c}0.147 \\
(0.076)\end{array}$ & $\begin{array}{c}0.028 \\
(0.088)\end{array}$ & $\begin{array}{c}0.094 \\
(0.048)\end{array}$ \\
\hline Contract, Van & $\begin{array}{c}0.375 \\
(0.502)\end{array}$ & $\begin{array}{c}0.097 \\
(0.071)\end{array}$ & $\begin{array}{c}0.225 \\
(0.258)\end{array}$ & $\begin{array}{c}0.097 \\
(0.041)\end{array}$ \\
\hline Contract, Not Van & $\begin{array}{c}0.422 \\
(0.386)\end{array}$ & $\begin{array}{c}-0.103 \\
(0.081)\end{array}$ & $\begin{array}{c}0.398 \\
(0.238)\end{array}$ & $\begin{array}{c}-0.001 \\
(0.054)\end{array}$ \\
\hline Common, Van & $\begin{array}{l}-0.223 \\
(0.438)\end{array}$ & $\begin{array}{c}0.280 \\
(0.062)\end{array}$ & $\begin{array}{c}0.364 \\
(0.151)\end{array}$ & $\begin{array}{c}0.228 \\
(0.038)\end{array}$ \\
\hline Common, Not Van & $\begin{array}{c}0.556 \\
(0.330)\end{array}$ & $\begin{array}{l}-0.020 \\
(0.106)\end{array}$ & $\begin{array}{c}0.152 \\
(0.191)\end{array}$ & $\begin{array}{c}0.116 \\
(0.056)\end{array}$ \\
\hline Log of likelihood fn. & & & & \\
\hline
\end{tabular}

Specifications are analogous to those in Table 3.

Bold indicates rejection of a two-tailed t-test of size 0.05 of $\mathrm{H} 0$ : beta $=0$. 


\section{Table 5}

\section{Distribution of EVMS-Related Capacity Utilization Increases, 1997}

\section{Column}

Label

Formula

All Trucks

Private, Van, Short

Private, Not Van, Short

Contract, Van, Short

Contract, Not Van, Short

Common, Van, Short

Common, Not Van, Short

Private, Van, Long

Private, Not Van, Long

Contract, Van, Long

Contract, Not Van, Long

Common, Van, Long

Common, Not Van, Long
(1)

\section{Coefficient}

Estimate

(2)

(3)

(4)

(5)

(6)

Share of Industry

EVMS

Adoption

Industry Share of

of Adopters in Cell Gains from Cell

Share of

"All Trucks" coefficient estimate is (OBC1+EVMS1) from the first column in Table 3.

Cell coefficient estimates are from the right panel of Table 4.

$\begin{array}{ccc}\mathbf{0 . 1 2 7} & 100.0 \% & 25.6 \% \\ \mathbf{0 . 4 0 4} & 2.7 \% & 15.1 \% \\ 0.028 & 11.8 \% & 7.0 \% \\ 0.225 & 0.9 \% & 10.0 \% \\ 0.398 & 0.7 \% & 15.8 \% \\ \mathbf{0 . 3 6 4} & 1.9 \% & 14.6 \% \\ 0.152 & 1.7 \% & 9.4 \% \\ & & \\ \mathbf{0 . 1 6 1} & 14.6 \% & 31.0 \% \\ \mathbf{0 . 0 9 4} & 18.2 \% & 16.6 \% \\ \mathbf{0 . 0 9 7} & 13.5 \% & 44.4 \% \\ -0.001 & 8.6 \% & 29.4 \% \\ \mathbf{0 . 2 2 8} & 16.1 \% & 34.3 \% \\ \mathbf{0 . 1 1 6} & 9.4 \% & 23.7 \%\end{array}$

$(2)^{\star}(3) \quad(1)^{*}(2)^{\star}(3)$

$25.6 \%$

$3.25 \%$

$100.0 \%$

$0.4 \%$

$0.8 \%$

$0.1 \%$

$0.1 \%$

$0.3 \%$

$0.2 \%$

$4.5 \%$

$3.0 \%$

$6.0 \%$

$2.5 \%$

$5.5 \%$

$2.2 \%$

$0.17 \%$

$0.02 \%$

$0.02 \%$

$0.04 \%$

$0.10 \%$

$0.02 \%$

$0.73 \%$

$0.28 \%$

$0.58 \%$

$-0.00 \%$

$1.26 \%$

$0.26 \%$

\section{$4.8 \%$}

$0.7 \%$

$0.6 \%$

$1.3 \%$

$2.9 \%$

$0.7 \%$

$20.9 \%$

$8.1 \%$

$16.6 \%$

$-0.1 \%$

$36.1 \%$

$7.4 \%$ 
Table A1

Coefficient Estimates - Multivariate Regressions

Dependent Variables: In(loaded miles), In(weeks in use

$\begin{array}{ll}\text { Delta Vector } & \text { OBC1 } \\ & \text { EVMS1 } \\ & \text { OBC2 } \\ & \text { EVMS2 }\end{array}$

Beta Vector

Area: $50-100$ Miles

Area: $100-200$ Miles

Area: $200-500$ Miles

Area: $>500$ Miles

Private Carriage

Contract Carriage

Owner-Operator: Independent

Owner-Operator: Subcontracto

Trailer: Lowboy

Trailer: Platform

Trailer: Refrigerated Van

Trailer: Logging

Trailer: Grain Body

Trailer: Dump

Trailer: Tank

Trailer: Other

LTL

$\mathrm{LTL}^{*}($ Area $<50)$

Gamma Vector C

Area: $50-100$ Miles

Area: 100-200 Miles

Area: $200-500$ Miles

Area: $>500$ Miles

Private Carriage

Contract Carriage

Owner-Operator: Independen

Owner-Operator: Subcontractor

Trailer: Lowboy

Trailer: Platform

Trailer: Refrigerated Van

Trailer: Logging

Trailer: Grain Body

Trailer: Dump

Trailer: Tank

Trailer: Other

LTL

$\mathrm{LTL}^{*}($ Area $<50)$

Model Year 1996 (1991 for 1992 specification'

Model Year 1995 (1990 for 1992 specification:

Model Year 1994 (1989 for 1992 specification'

Model Year 1993 (1988 for 1992 specification

Model Year 1992 (1987 for 1992 specification.

Model Year 1991 (1986 for 1992 specification:

Model Year 1990 (1985 for 1992 specification'

Model Year 1989 (1984 for 1992 specification:

Model Year 1988 (1983 for 1992 specification

Model Year 1987 or before (1982 for 1992 specification

Alpha Vector

Farm Products

Live Animals

Lambda

Bold indicates rejection of a two-tailed t-test of size 0.05 of $\mathrm{HO}$ : beta=0
1997

Estimate Std.Err.

$0.023 \quad 0.027$

$0.104 \quad 0.028$

$0.056 \quad 0.031$

$-0.078$

0.032

$10.037 \quad 0.029$

$0.178 \quad 0.028$

$0.454 \quad 0.031$

$0.753 \quad 0.031$

$1.009 \quad 0.030$

$\begin{array}{ll}-0.118 & 0.021\end{array}$

$0.086 \quad 0.020$

$0.216 \quad 0.036$

$0.264 \quad 0.032$

$0.023 \quad 0.040$

$0.031 \quad 0.023$

$-0.021 \quad 0.025$

$0.474 \quad 0.054$

$0.533 \quad 0.052$

$\mathbf{0 . 3 6 3} \quad \mathbf{0 . 0 3 3}$

$0.034 \quad 0.032$

$-0.113 \quad 0.024$

$-0.091 \quad 0.025$

$-0.161 \quad 0.059$

$-$

0.467

0.486

0.444

0.305

$-0.176$

$-0.027$

$-0.298$

$-0.231$

$-0.512$

$-0.147$

0.097

$-0.264$

$-0.958$

$-0.138$

0.013

$-0.051$

0.024

0.599

0.229

0.202

0.154

0.118

0.114

0.029

$-0.070$

$-0.076$

$-0.190$

$-0.643$

$-0.174$

$-0.190$

0.406

0.031

0.034

0.034

0.033

0.024

0.023

0.040

0.037

0.045

0.026

0.028

0.062

0.056

0.038

0.036

0.027

0.029

0.067

0.024

0.023

0.025

0.026

0.030

0.031

0.029

0.029

0.030

0.023

0.011

0.019

0.010
1992

Estimate Std.Err.

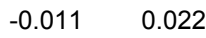

$0.022 \quad 0.027$

$0.144 \quad 0.025$

$\begin{array}{ll}-0.100 & 0.030\end{array}$

$10.008 \quad 0.024$

$0.264 \quad 0.020$

$0.527 \quad 0.023$

$0.778 \quad 0.022$

$0.993 \quad 0.022$

$\begin{array}{ll}-0.134 & 0.017\end{array}$

$0.091 \quad 0.017$

$0.117 \quad 0.028$

$0.239 \quad 0.025$

$0.029 \quad 0.031$

$0.023 \quad 0.019$

$0.002 \quad 0.020$

$0.277 \quad 0.039$

$0.475 \quad 0.040$

$0.359 \quad 0.026$

$0.011 \quad 0.024$

$\begin{array}{ll}-0.208 & 0.019\end{array}$

$\begin{array}{ll}-0.082 & 0.023\end{array}$

$-0.405 \quad 0.042$
$0 . \overline{16} \quad 0.022$

$0.339 \quad 0.025$

$0.300 \quad 0.025$

$0.196 \quad 0.025$

$\begin{array}{ll}-0.230 & 0.019\end{array}$

$-0.063 \quad 0.018$

$-0.114 \quad 0.031$

$-0.164 \quad 0.027$

$-0.656 \quad 0.034$

$-0.159 \quad 0.021$

$0.077 \quad 0.022$

$-0.091 \quad 0.044$

$\begin{array}{ll}-0.790 & 0.044\end{array}$

$-0.214 \quad 0.028$

$0.011 \quad 0.027$

$0.006 \quad 0.021$

$\begin{array}{ll}-0.015 & 0.025\end{array}$

$0.463 \quad 0.047$

$0.375 \quad 0.022$

$0.415 \quad 0.021$

$0.339 \quad 0.020$

$0.288 \quad 0.021$

$0.241 \quad 0.022$

$0.146 \quad 0.023$

$0.094 \quad 0.023$

$0.044 \quad 0.022$

$0.006 \quad 0.029$

$\begin{array}{ll}-0.529 & 0.018\end{array}$

$\begin{array}{ll}-0.185 & 0.009\end{array}$

$-0.179 \quad 0.016$

$0.431 \quad 0.008$ 


\section{Table A2}

\section{Cross-Sectional Interactions - 1992}

\begin{tabular}{|c|c|c|c|c|c|}
\hline \multirow{2}{*}{ OBC1 } & & \multicolumn{2}{|c|}{ Length of Haul } & \multicolumn{2}{|c|}{ Length of Haul } \\
\hline & & Short & Long & Short & Long \\
\hline & Private, Van & $\begin{array}{c}0.674 \\
(0.135)\end{array}$ & $\begin{array}{l}-0.145 \\
(0.041)\end{array}$ & & \\
\hline & Private, Not Van & $\begin{array}{c}-0.004 \\
(0.085)\end{array}$ & $\begin{array}{c}0.007 \\
(0.052)\end{array}$ & & \\
\hline & Contract, Van & $\begin{array}{c}0.015 \\
(0.331)\end{array}$ & $\begin{array}{l}-0.085 \\
(0.066)\end{array}$ & & \\
\hline & Contract, Not Van & $\begin{array}{l}-0.356 \\
(0.236)\end{array}$ & $\begin{array}{c}-0.112 \\
(0.074)\end{array}$ & & \\
\hline & Common, Van & $\begin{array}{c}0.426 \\
(0.237)\end{array}$ & $\begin{array}{l}-0.100 \\
(0.067)\end{array}$ & & \\
\hline & Common, Not Van & $\begin{array}{l}-0.266 \\
(0.178)\end{array}$ & $\begin{array}{c}0.323 \\
(0.070)\end{array}$ & & \\
\hline \multicolumn{6}{|c|}{ EVMS1 } \\
\hline & Private, Van & $\begin{array}{c}-0.673 \\
(0.227)\end{array}$ & $\begin{array}{c}0.158 \\
(0.058)\end{array}$ & $\begin{array}{l}-0.048 \\
(0.189)\end{array}$ & $\begin{array}{c}0.043 \\
(0.048)\end{array}$ \\
\hline & Private, Not Van & $\begin{array}{c}-0.385 \\
(0.131)\end{array}$ & $\begin{array}{c}0.153 \\
(0.079)\end{array}$ & $\begin{array}{c}-0.390 \\
(0.104)\end{array}$ & $\begin{array}{c}0.160 \\
(0.063)\end{array}$ \\
\hline & Contract, Van & $\begin{array}{l}-0.271 \\
(0.655)\end{array}$ & $\begin{array}{c}0.108 \\
(0.076)\end{array}$ & $\begin{array}{l}-0.256 \\
(0.573)\end{array}$ & $\begin{array}{c}0.031 \\
(0.046)\end{array}$ \\
\hline & Contract, Not Van & $\begin{array}{c}0.443 \\
(0.441)\end{array}$ & $\begin{array}{l}-0.057 \\
(0.092)\end{array}$ & $\begin{array}{c}0.104 \\
(0.380)\end{array}$ & $\begin{array}{l}-0.158 \\
(0.063)\end{array}$ \\
\hline & Common, Van & $\begin{array}{l}-0.120 \\
(0.368)\end{array}$ & $\begin{array}{c}0.189 \\
(0.070)\end{array}$ & $\begin{array}{c}0.296 \\
(0.286)\end{array}$ & $\begin{array}{c}0.097 \\
(0.035)\end{array}$ \\
\hline & Common, Not Van & $\begin{array}{c}0.247 \\
(0.284)\end{array}$ & $\begin{array}{c}-0.499 \\
(0.087)\end{array}$ & $\begin{array}{c}-0.002 \\
(0.231)\end{array}$ & $\begin{array}{l}-0.201 \\
(0.059)\end{array}$ \\
\hline & Log of likelihood fn. & \multicolumn{2}{|c|}{-68183} & \multicolumn{2}{|c|}{-68219} \\
\hline
\end{tabular}

Specifications are analogous to those in Table 3.

Bold indicates rejection of a two-tailed t-test of size 0.05 of $\mathrm{HO}$ : beta $=0$ 